\title{
LA EMIGRAGIÓN FORZADA DE 1939 EN LOS NIÑOS DE RUSIA, EL SUEÑO DERROTADO Y EXILIO
}

\author{
Thomas Deveny
}

McDaniel College

La migración es innata al ser humano a lo largo de la historia, y España siempre ha presenciado el ir y venir de gente con aspiraciones de vivir una vida mejor. Desde los pueblos de la historia antigua que llegaron a la península hasta los inmigrantes actuales, España ha visto diversas olas de personas que han venido a esta tierra. Pero muchos también han salido buscando sus fortunas, desde las expediciones de conquistadores que fueron al Nuevo Mundo hasta las personas que hoy en día aprovechan las nuevas leyes para buscar trabajo en otros países de la Unión Europea. Esta emigración ha sido un tema importante en el cine español desde sus comienzos: Segundo de Chomón rodó El emigrante en 1915; en décadas recientes, hemos visto películas que nos hablan de la emigración hacia América (Frontera sur, de Gerardo Diego) o hacia el norte de Europa durante los años sesenta: El techo del mundo, de Felipe Vega, El tren de la memoria dirigida por Marta Arribas y Ana Pérez, o Un franco, catorce pesetas, de Carlos Iglesias. Paul Ilie (1980: 6) opina que España es "un país con una historia y una tradición de migración y exilio a lo largo de siglos como una condición inherente a la cultura española centenaria" y subraya el número de palabras que hay en el castellano por las que la lengua "traiciona una conciencia atribulada de exilio: desterrados, exiliados, emigrantes, emigrados, transterrados, peregrinos, despatriados, y transplantados" ${ }^{11}$. Los sociólogos dividen los factores de emigración entre dos tipos: los de empuje y los de atracción. Mientras que el factor de atracción más importante es la posibilidad de empleo en un país más desarrollado, los factores de empuje incluyen la persecución, los desastres naturales o la pobreza extrema (Marshall, 2006: 3). La emigración forzada -el exilio- corresponde a este último tipo y es quizá la forma más difícil de emigración tanto psicológica como físicamente. A lo largo del siglo XX, el momento de emigración más fuerte fue 1939, cuando medio millón de españoles tuvieron que salir de España hacia el exilio². Según Vicente Lloréns, "'Nunca en

1 Todas las traducciones al español son mías.

2 Sólo se puede considerar un reflejo de la época que en un estudio sobre la emigración española por lo demás exhaustivo por Jesús García Fernández que se publica en 1965, hace caso omiso de esta emigración forzada y llega a declarar que entre 1936-46 la emigración exterior "en ningún año llegó a los 5.000 emigrantes y generalmente fue inferior a los 2.000" (García Fernández, 1965: 14). La Organización Mundial para las Migraciones 
la historia de España se había producido un éxodo de tales proporciones ni de tal naturaleza" (Abellán, 1983: 59). Tres documentales recientes dan testimonio a esta emigración forzada: Los niños de Rusia, de Jaime Camino (2001), Exilio, de Pedro Carvajal (2002), y El sueño derrotado (2004), de Daniel y Jaime Serra.

En teoría, los documentales pueden tomar diferentes formas. Para Bordwell y Thompson (1990: 130), la película de recopilación utiliza imágenes de fuentes de archivo, mientras que los documentales de entrevista graban testimonios sobre eventos o movimientos sociales, y denomina las películas que combinan varios enfoques o estilos como documentales sintéticos. Nichols teoriza que hay documentales expositivos o interactivos. El documental expositivo contiene "comentario de la voz de Dios y perspectivas poéticas que intentan revelar información sobre al mundo histórico en sí y de ver ese mundo de nuevo, aun si esas perspectivas parecen románticas o didácticas [...] el texto expositivo se dirige al público directamente con títulos o voces que avanzan un argumento sobre el mundo histórico" (Nichols, 1991: 34). En cambio, el documental interactivo no tiene la exposición clásica; el cineasta puede narrar los eventos del pasado por medio de testigos y expertos que el público también puede ver. Una secuencia de archivo de los eventos del pasado se añade a estos comentarios para evitar los peligros de la recreación y las reclamaciones del comentario de la voz de Dios. Así "el documental interactivo hace hincapié en las imágenes de testimonio y de intercambio verbal y las imágenes de demostración (imágenes que demuestran la validez, o posiblemente la falta de certeza de lo que dicen los testigos)" (Nichols, 1991: 44).

\section{LOS NIÑOS DE RUSIA}

Los niños de Rusia, de Jaime Camino, es un documental sintético e interactivo sobre los niños republicanos que fueron evacuados del País Vasco durante la Guerra civil y acabaron en Rusia. Carece de narrador; escuchamos los testimonios de los exiliados con imágenes de archivo para confirmar esos testimonios. Los padres pusieron a unos tres mil niños en barcos con destino a Rusia o Francia durante el sitio a Bilbao. Muchos se quedaron en Rusia; otros emigraron de nuevo a Cuba; algunos volvieron a España a mediados de los años cincuenta, después de la muerte de Stalin, pero la mitad de ellos regresaron de nuevo a Rusia. Jaime Camino nunca identifica a los entrevistados, así que es difícil atribuir testimonios a individuos específicos. De vez en cuando mencionan sus nombres. Aunque la mayoría de las entrevistas se hicieron en espacios neutros, a veces tienen lugar en las casas de los entrevistados, y algunos detalles como las muñecas rusas que adornan una mesa expresan el impacto de vivir en Rusia. Jaime Camino yuxtapone temáticamente las narraciones de los sobrevivientes; algunos temas son como hilos narrativos que aparecen a lo largo de la película.

reconoce la "migración forzada" como una de las categorías fundamentales de las migraciones y la define como "el movimiento no voluntario de una persona que desea escaparse de un conflicto armado o de una situación violenta [...] o de una catástrofe o bien natural o bien debido al ser humano" ("Approaches", 2003: 9). La diáspora de España en 1939 cabe dentro de esta definición. La cifra de medio millón es la que más se usa (por ejemplo, Aguilar, 1999: 84). Hugh Thomas (1977: 920) habla de los miles de refugiados que llegaban a Francia de los puertos mediterráneos y se sumaban a los "400.000 o más" que habían huido de Cataluña. Abellán (1983: 59) concluye que "el cómputo no puede situarse por debajo de los 300.000 exiliados". En contraste, otros años de emigración fuerte durante el siglo XX no llegan a la mitad de esta cifra: 1906-10 tienen un promedio de 144.050 y $1962-63$ tienen un promedio de 186.051 (García Fernández, 1965: 22, 34). 
El texto con que empieza la película da una breve explicación del contexto histórico, pero decir que los niños fueron "evacuados temporalmente" capta el idealismo y los sentimientos erróneos del momento. Hay una ironía en la creencia que tenían muchos de ellos de que el conflicto durara poco y que sin duda habría una victoria republicana. Una mujer declara que su padre decía que "iba a terminar la guerra e íbamos a ganar, entonces volveríamos en seguida", frases que manifiestan lo que sería una falsa esperanza.

A lo largo de la película, vemos tanto fotos personales como fotos y secuencias de archivo. Por ejemplo, cuando los entrevistados mencionan los bombardeos que sufrieron, Jaime Camino incluye una secuencia de estos eventos históricos para corroborar su testimonio. La secuencia de archivo más larga y de más impacto emocional es de la salida misma: niños con "letreritas" en los cuellos que indican su destino; padres abrazando y besando a sus hijos; niños llorando. Como indica uno de los entrevistados que acompañaba a los niños como adulto joven, fue "trágico" porque "llegaron los padres con los niños, con los hijos, y nosotros teníamos que quitarles de los brazos", y otro opina que lo fue porque "los niños que tienen que emigrar sin que ellos decidan". Otros detalles de impacto emocional indican lo que era importante para un niño en ese momento: un hombre recuerda como regaló todas sus canicas a sus compañeros que se quedaron en España.

Los testimonios sobre el viaje a Rusia por barco destacan las dificultades del traslado: los niños tenían hambre, había ratas enormes en el barco, los niños no podían comunicarse con los marineros porque eran chinos o vietnamitas. Una mujer cuenta que cuando el barco atracó en Francia, quiso desembarcar cuando vio la recepción que recibieron los otros niños: pan y chocolate. Luego una secuencia de archivo del noticiero ruso sobre la llegada a Rusia contiene la retórica del momento: los "fascistas salvajes" destruyeron ciudades y pueblos y mataron e hirieron a mujeres y niños indefensos, y por eso los niños tuvieron que abandonar España. El noticiero confirma la memoria de los adultos de que se bajaron del barco con el puño en alto, y que fueron recibidos por centenares de pioneros rusos uniformados y con pañuelos rojos. El testimonio sobre este evento también tiene sus momentos cómicos, como cuando una mujer recuerda que los rusos preguntaron a los niños: "¿Familia?" y sin saber que esto significa "¿apellido?" en ruso, todos decían, "¿Familia? Bilbao".

Desplazarse a otro país frecuentemente significa la necesidad de adaptarse a otra cultura, y la comida y la lengua son dos componentes fundamentales en este proceso. La comida es siempre un componente de películas sobre la emigración y aquí tiene un elemento de ironía: los niños tenían mucha hambre y los rusos les sirvieron bocadillos con caviar. Y esta necesidad primaria de comer conlleva otra necesidad en el contexto migratorio: aprender un nuevo vocabulario, un nuevo idioma. Una custodia de los niños manifiesta esto, usando un cambio de registro lingüístico (empleando palabras rusas), lo cual es un fenómeno común en emigrantes que tienen que cambiar de idioma: "'Trisca,' bacalao. Los niños gritaron, tavari, hoy hay bacalao. Y después chichivicha, que son lentejas". Sin embargo, varios de los entrevistados mencionan que estudiaron todas sus materias en español y que la lengua rusa fue una clase aparte. Secuencias de archivo acompañan la sección sobre la educación de los niños, y el uso de una cortinilla entre tomas de una clase de matemáticas y otra de geografía indican un elemento estilístico del cine ruso de la época.

Emigrar a un país con otra religión puede ser problemático, y en este documental la religión es otro tema importante, tanto para los que se quedaron en Rusia como para los que regresaron a España. Una mujer habla de las dificultades al comienzo de su estancia en Rusia: 
"yo era una niña muy religiosa. Empezaron a educarnos en el ateísmo y yo sufría mucho". Una secuencia de archivo de Franco en una iglesia española hace hincapié en la importancia de la religión durante el régimen, y las narraciones de los entrevistados manifiestan la falta de tolerancia y un aspecto ridículo del ambiente religioso de esa época. Cuando uno de los entrevistados volvió a España y dijo a un cura que no era creyente, y "me llamó perro, bestia, animal". Otro, al regresar, daba un paseo con su hermano y su cuñada rusa, y una mujer se les acercó y preguntó, "¿Pero dónde están los cuernos y el rabo que tienen los rusos?". Y cuando el hombre le preguntó "¿Quién le ha dicho eso a usted?", la mujer contestó: "El cura me lo dijo". Y para los que se quedaron en Rusia, ha habido un cambio allí en los últimos años: la religión tiene un papel cada vez más importante en la sociedad rusa de hoy en día, y una secuencia actual muestra a curas y feligreses para confirmar este testimonio.

La invasión de los nazis y el papel de Rusia en la Segunda Guerra Mundial tuvieron un impacto muy importante en los niños. Dos mujeres recuerdan exactamente el momento en que escucharon el anuncio por parte de Molotov: Araceli nota que ocurrió durante un partido de fútbol cuando el equipo Euzkadi de Bilbao vino para jugar; otra mujer recuerda que estaba preparándose para una fiesta, planchando una falda. Una secuencia de archivo ruso de la invasión capta gráficamente el horror de la guerra y habla de las atrocidades cometidas por los nazis. Los testimonios de cómo tenían que recoger bombas sin detonar y colocarlas en cubos de agua para que no detonaran son impactantes. Y también lo son las historias del frío horrible de Rusia: cuarenta grados bajo cero. Un emigrante lleva bagaje cultural consigo y un testimonio tiene un toque español cuando un hombre indica que con "ese aire gélido, se congela María Santísima". Aunque otra secuencia de archivo capta la felicidad al terminar la guerra, los testimonios expresan más dificultades. Uno recuerda que parejas recién casadas "vivíamos en albergues, se casaba la gente y se tapaba con sábanas para hacer las intimidades porque era una habitación de veinte personas".

La repatriación de los españoles en 1957 es otro tema que incluye secuencias de archivo y testimonios personales. Araceli Sánchez, que hace una narración muy detallada de la salida, la hace otra vez, diciendo de su padre, "Y mi padre, la emoción no pudo y era un hombre que era campeón de bolos vasco se agarró a un tronco de árbol y se cayó al suelo de la emoción". La migración de vuelta a un país de origen puede ser difícil, sin embargo, y muchos de los exiliados dan testimonio de las dificultades emocionales. La secuencia de archivo que seleccionó Jaime Camino para acompañar estos testimonios hace hincapié en el abismo que separaba a las personas que regresaban de la sociedad española que encontraban. Una imagen de un pueblo con el yugo y las flechas a la entrada con un campanario al fondo establece el ambiente cultural del franquismo, que sería radicalmente diferente al que estaban acostumbrados en Rusia. Con razón una mujer declara: "No tenías ya mucha afinidad con la gente. Nosotros ya éramos ajenos para ellos". De igual manera, una foto de archivo de un limpiabotas debajo de un cartel que anuncia la película Ay pena, penita, pena con Lola Flores, capta las emociones de un hombre que habla de sus problemas al buscar trabajo porque "nadie quería comprometerse" con él visto que había vivido en Rusia. Otra entrevistada hace una confesión medio coherente que refleja sus dificultades emocionales: "Cuando abracé a mi madre, es terrible, yo no sé, creo que nos ha pasado a muchos, quizá porque no me había educado con ella, será porque habían pasado muchos años, pero sabes lo doloroso que es tratarte con una persona que es tu familia, tu madre o tu hermano, y que prácticamente no sientes nada. Fue muy triste ese encuentro y no la volví a ver más". 
Los testigos ofrecen cartas que sirven como pruebas documentales en dos ocasiones. El primer caso se refiere a la conducta de los niños españoles durante los momentos más oscuros de la Segunda Guerra Mundial. Una mujer dice, "Tengo aquí estas cartas del director de la casa de niños. Él habla del valor, del heroísmo de los niños españoles en Leningrado". Más tarde, Piedad Vega de la Iglesia lee una carta que escribió su padre a ella y sus hermanos desde un campo de concentración en el pueblo de Albatera la noche antes de que lo fusilaran los nacionalistas. Como documento, esta carta es indicativa de una de las muchas víctimas de las represalias del franquismo:

Queridísimos hijos Piedad, Ernestito y Paquito: Nosotros que hasta hora habéis vivido en un mundo lleno de rosas y que habéis vivido felices con mamá y conmigo no podéis comprender hoy por qué muero yo. Cuando seáis mayores, cuando la vida os haga comprender sus misterios y su dureza, cuando sepáis cómo son los hombres, entonces sabréis que vuestro padre, que fue bueno toda la vida, que no sólo no hizo mal a nadie sino que sacrificó su porvenir y su vida por una vida mejor, dejó esta...

Como con todo emigrante, la cuestión de identidad es primordial, y este es el último tema de la película. Estos individuos biculturales que tuvieron que emigrar de España como niños no pueden sino manifestar cierta ambigüedad hacia su identidad. Un hombre declara, "Es difícil decir si soy más ruso o más español. Me sigo sintiendo español. Completamente". Otro comenta "sentirse desarraigado de su tierra, eso es muy duro". Y una mujer que emigró de nuevo -de Rusia a Cuba- habla de sus problemas de identidad: "no somos de nadie, nunca fuimos de nadie nosotros. En la URSS eras español. En Cuba, eres hispano-soviético. A España cuando iba primero, era "Vino la rusa". Y ahora cuando voy, "Vino la cubana". Española nunca fui, vaya".

La memoria en sí es a veces tema de la película; los entrevistados usan el verbo "recordar" frecuentemente. La habilidad de recordar vacila entre los entrevistados que admiten cierta dificultad en recordar por una parte y descripciones vívidas que captan conversaciones y que pintan algunas escenas con detalles dramáticos. Estas metamemorias ocurren con más frecuencia al comienzo de la película con el componente temático que corresponde al comienzo de su narración: su salida de España. Araceli Sánchez da descripciones increíblemente detalladas que utilizan tiempos verbales que indican la eliminación del pasaje del tiempo: "Con su mochilita los estoy viendo ahora, como subían por las escaleras del barco [...] y se volvían a ellos y con las manitas los hacían adiós, adiós. Y mi madre me decía, 'No llores, que nos vean reír, no llores, no llores. Que nos vean que estamos contentos. Y cuando se fue [el barco] mi madre se cayó al suelo gritando como una loca". Otro ejemplo de la metamemoria es el siguiente: "lo que recuerdo es una pena muy grande, que dejabas, pues, a los familiares, a todos y, sin embargo, la alegría de marcharte de las bombas". El uso del pretérito perfecto y el presente del indicativo también hace hincapié en la memoria: "yo creo que lo más terrible de mi vida ha sido oír gritos y ver llorar a miles de niños cuando llegó la noticia" de que Bilbao había caído; "¿dónde están los padres y las madres?". El cambio de tiempos verbales también indica la compresión del tiempo en la mente de los testigos: "cuando nos acostábamos, yo me acuerdo aún mucho de mis padres". Por otra parte, una mujer admite que tiene dificultad en recordar el comienzo de su estancia en Rusia: "yo no me acuerdo mucho porque era todo tan raro para unos meses". 


\section{EL SUEÑO DERROTADO}

El sueño derrotado es un documental sintético que también mezcla entrevistas con imágenes de archivo. Cuenta con entrevistas de diecisiete hombres y mujeres que emigraron forzosamente al terminar la guerra civil. Este documental tiene un elemento importante del género expositivo: un narrador comienza el discurso histórico que ofrece el contexto del exilio mientras vemos imágenes de la guerra: "El 18 de julio de 1936, un grupo de militares encabezado por el general Franco se alza contra el gobierno democrático de la República [...] A finales de 1938, el régimen que creó las autonomías, que dio el derecho a voto a las mujeres e instituyó la escolarización gratuita y obligatoria, agoniza". Así, en unas escuetas líneas, la historia salta del comienzo de la guerra al final para abrir la narración de la emigración forzada. Y esta contextualización obviamente hace paralelos entre la España contemporánea que goza de unos aspectos políticos y sociales que también tenía la República, aclarando así el título del documental y destacando su punto de vista narrativo.

Los directores agrupan los comentarios de los entrevistados alrededor de varios temas: el idealismo mantenido hasta el último momento de la guerra; la retirada y salida de España; la llegada a Francia; el campo de concentración en Argelés; el papel de los exiliados españoles en la Segunda Guerra Mundial; la experiencia de tres de los entrevistados en el campo de exterminio de Mauthausen; y el devenir de los españoles exiliados en Francia al terminar la guerra.

El idealismo de estos republicanos se manifiesta en un comentario de Matías Arranz: "Lo teníamos tan arraigado y estábamos tan convencidos que, hasta el último momento, hemos creído que podíamos ganar". Las imágenes de civiles que huyen desmienten ese idealismo e ilustran los comentarios del narrador en off: "cientos de miles de personas abandonan todo lo que tienen y huyen hacia la frontera siguiendo al ejercito".

Con esta emigración forzada, la necesidad de salir dejaba a muchos con un sentido de incredulidad; Julián Antonio Ramírez explica: "Y pasar a otro país para vivir una larga temporada en otro país yo todavía no me lo creía". También había un sentido de desorientación que se escucha en uno de los comentarios inolvidables de la película. Joan Pujol dice: "No sabes dónde vas, no teníamos mapa, no sabíamos donde íbamos. Cuando salíamos de Barcelona, fue por vía del tren que sabíamos que esta vía iba a Francia, pero nada más".

La mezcla de tiempos verbales en las entrevistas es frecuente y manifiesta un sentido atemporal de los acontecimientos; es como si los entrevistados estuvieran reviviendo estos momentos extraordinarios de hace casi sesenta años. Carmen Casas comenta, "Allí me pierdo de los compañeros que iban conmigo [...] y me encuentro en plena calle sin maleta". Algunos, como Josefina Piquet, repiten el verbo "me acuerdo" muchas veces, subrayando así esta metaacción de la memoria: "yo me acuerdo que en la carretera había muchos camiones [...] Yo en la frontera me acuerdo que nos separaron". De igual manera, Josefina Piquet, al subrayar el componente emocional, marca lo perdurable de ese momento lejano: "A mi madre la he visto llorar muy poco, pero aquellas lágrimas de mi madre es que las tengo aquí adentro". Otro aspecto importante de recordar es tener evidencia física de aquel momento. Joan Pujol afirma: "yo sólo iba con una chaqueta nada más y [un soldado republicano] me dio la famosa manta que llevaban los militares y la tengo todavía como recuerdo inolvidable".

Otro elemento psicológico de la emigración es la tristeza de tener que abandonar el país. Concha Pérez manifiesta: "Íbamos depauperadas, sucias, además de tanto llorar, bueno 
aquello era un cuadro, nos mirábamos el uno al otro y nos dábamos pena". El peligro físico no era solamente pasar los Pirineos en febrero sino que la aviación nacional ametrallaba a los civiles que huían. Los directores usan la técnica que es común en los documentales de hacer una panorámica en primer plano de fotografías de archivo y aquí vemos imágenes de civiles en el camino o de cadáveres de niños matados durante la persecución.

La sección sobre el campo de concentración en Argelés manifiesta una combinación de dificultades emocionales y físicas que sufrieron los exiliados por una parte con la solidaridad que les permitió organizarse, ayudarse y sobrevivir en condiciones tan difíciles por otra. Las dificultades emocionales surgían especialmente de la separación y la humillación. Los franceses separaron los hombres de las mujeres y los niños (Marcelina Urías: "me acuerdo de mi padre, que no quería mi madre dejarle"). Una de las imágenes más desgarradoras de esta sección es la foto de un hombre en un lado de un cerco con alambre y una mujer con dos niños en el otro, y el hombre pone los brazos entre el alambre para tocar a sus seres queridos. La humillación se debía a lo que Lluís Martí llama el "trato bestial" por parte de las autoridades francesas. $Y$ en uno de los pocos momentos en que se nota una conexión directa entre entrevistado y entrevistador, Concha Pérez observa (otra vez usando el presente del indicativo): "Nos hacen desnudar a todos, hombres y mujeres y niños" para ducharnos, y "Abajo, autoridades, gente, todos mirando, gendarmes, todos mirando como se nos duchaba, y sin una toalla para poderte secar ni poderte envolver... Imagínate tú lo que representaba para una madre encontrarse desnuda delante de su padre viejo o de sus hijos". También había humillación por parte del pueblo, ya que los franceses iban al campamento para mirarlos, como si fueran animales en un zoológico. Jaume Álvarez comenta que un niño preguntó a su madre: "Mamá, ¿dónde tienen el rabo estos señores?" visto que "la iglesia les había dicho que éramos demonios". Por otra parte, se nota el orgullo de los entrevistados por "el espíritu de solidaridad [...] que prevaleció" (Julián Antonio Ramírez). Varias fotos comprueban el progreso que hubo en el campo: la madera en pilas se transforma en barracas, y la intendencia del campamento se nota en las filas de pilas en que los exiliados lavan sus platos. La tristeza de la separación se volvía en la alegría de los reencuentros debido a que se organizaba un tablón donde todos ponían fotos de sus seres queridos y notas que decían que "fulana de tal reclama a su padre" (Laia Berenguer). Aquí los directores usan la técnica de hacer tres tomas en primer plano de la misma foto de familia, subrayando así el tema de la separación y la unificación.

Para dar variedad a las entrevistas, además de filmar a estos testigos de la historia sentados en sus casas, los directores optan por volver a lo que Pierre Nora (1984: xxxiv) llama "lugares de memoria". En este caso, la playa donde estaban el campamento de Argelés y el campo de concentración abandonado de San Ciprién. Antonio de la Fuente camina entre las ruinas de los edificios y explica cómo vivían o, quizá mejor dicho, sobrevivían. A pesar del frío horrible y la tramontana de que se quejan varios de los entrevistados, encuentran un elemento poético en su sufrimiento: tenían "como manta, las nubes y como abrigo, las alambradas". De igual manera, la fotografía de este segmento del documental tiene un aspecto poético, con las tomas en primer plano del alambre de púa que todavía existe entre las hojas de las plantas que se mueven en el viento.

La invasión de Polonia en 1939 cambió el porvenir de los españoles en esos campos porque, como observa Lluís Martí, los franceses se veían "obligados a cogernos como mano de obra (...) esclava, ahí está la cosa". La panorámica en primer plano de una foto de los es- 
pañoles con palas cavando trincheras en la nieve manifiesta que salir de los campamentos no resultaba una fiesta, ni mucho menos. Los españoles también se incorporaron a la lucha contra los nazis, porque como observa Julián Antonio Ramírez, "Éramos los que sabíamos hacer la guerra [...] así nos tocaban las misiones de más responsabilidad y también de más peligro". Fotos de los soldados españoles armados confirman este nuevo papel.

El segmento más impactante del documental tiene que ver con la estancia que pasaron Matías Arranz, Jaume Álvarez y Francisco Ortiz en el campo de exterminio de Mauthausen. Por más que uno vea imágenes de los campos de exterminio, o por más que uno escuche testimonios de sobrevivientes, es siempre desgarrador ver y escucharlos de nuevo. Como afirma Matías Arranz, "formábamos parte del mundo de los muertos en vida", y las imágenes de alemanes con sus uniformes acompañados por sus perros y los presos (incluso mujeres y niños) con sus trajes a rayas, los hombres desnudos como esqueletos, el crematorio, la cantera donde tenían que trabajar como esclavos son parte de la memoria histórica que nunca hay que olvidar. Los tres sobrevivientes cuentan detalles sobre cómo funcionaba el campo (la forma sin escrúpulos en que escogían al azar a presos para eliminarlos; cómo los nazis identificaban a los diversos tipos de presos -judíos, homosexuales, españoles...- con triángulos de diferentes colores) hasta detalles muy íntimos: Julián Antonio Ramírez cuenta cómo vomitaba al descargar de un tren los cadáveres que llegaban de los otros campos que los nazis iban abandonando al final de la guerra; Francisco Ortiz admite, "yo he querido suicidarme allí". Al final la mirada de satisfacción que se ve por parte de Julián Antonio Ramírez en primer plano es justificada: "Mi única esperanza era eso, salir para cagarme en la madre que los parió. Y así fue".

El último segmento de la película tiene una secuencia de archivo de los desfiles en París para festejar el fin de la guerra; Lluís Martí comenta, "En todo el trayecto, los que llevaron la ovación y no pararon en todo el trayecto de aplaudirnos fuimos los españoles". Sin embargo, la euforia acabó como el final del documental: estos exiliados ahora sienten "disgusto" (Julián Antonio Ramírez) por al abandono de los países democráticos y victoriosos, y María Amparo Sánchez opina que los españoles republicanos eran "los únicos vencedores [...] que quedaron vencidos después de esa victoria".

\section{EXILIO}

Este documental sintético de Pedro Carvajal consta de entrevistas con unos cincuenta y dos republicanos exiliados y algunos extranjeros que añaden información a los testimonios de los españoles. También sigue la línea del documental expositivo; tiene un narrador en off (voz de Dios), pero se usa poco. Comienza con un resumen muy escueto de la contienda, destacando la neutralidad de los países democráticos y los asesinatos de muchos civiles por parte de los falangistas (General Mola: "cualquier defensor del Frente Popular debe ser fusilado").

El análisis de eventos públicos en el exilio-los entierros de exiliados famosos- nos revela un cambio en la actitud por parte de los franceses hacia los exiliados. José Martínez Cobo observa que cuando los refugiados llegaron a Francia, se les llamaban rojos, pero durante los años siguientes, "los españoles, las españolas, los hijos han demostrado que saben trabajar, saben sufrir, educar a sus hijos, luchar por la libertad de Francia". En 1945, "ya no son los rojos, son los republicanos, el término rojo desaparece". Como ilustración de este cambio, 
menciona que cuando muere Azaña en 1940, "el entierro es mísero, no hay nadie", pero cuando fallece Largo Caballero, en 1946, es un entierro oficial con banda; un millón de personas acuden. Una foto del coche fúnebre y las multitudes confirman su testimonio. Martínez Cobo declara: "Yo me atrevería a decir que los exiliados cambian la visión que Francia tiene de España".

Como ocurre con cualquier emigrado, pero especialmente con el emigrado que sale por factores de empuje (y más cuando uno sale del país de niño), hay una nostalgia por lo perdido y la cuestión de una identidad dividida. Como opina Tina Sangrones, "te falta tu familia, te falta tu país, te faltan tus raíces". Las cuestiones de identidad que se revelan en pequeños detalles de la vida cotidiana: José María Astorga admite que cuando hay un partido de fútbol entre España y Bélgica, "me pongo nervioso". Y Aurora Molina declara, "Soy española y soy mexicana y no puedo prescindir de ninguna de las dos".

Exilio complementa la información que hay en El sueño derrotado sobre la emigración hacia Francia, los campos de concentración en Francia, y la suerte de los españoles al salir de los campos, añadiendo algunos detalles significativos. Araceli Sánchez ofrece testimonio doloroso, ya que poco antes de llegar a la frontera, cayó una bomba que "arrancó a manos de mi mamá a mi hermana" y, luego, "un camión rodó sobre [ella]" y la mató. Juan Martínez Cobo nos informa que la Cruz Roja francesa "no pisa los campos de concentración, no se ocupa de los refugiados" y que son los cuáqueros americanos e ingleses y la Cruz Roja suiza quienes traen comida y medicamentos y luego tratan de intervenir a favor de los presos. La inglesa Farah Meldleshon confirma la labor de los cuáqueros. Eulalio Ferrer explica que en San Ciprién mucha gente murió de disentería porque al principio no había donde ir al baño aparte de la orilla del mar. Y da testimonio sobre la dificultad de la vida al abandonar los campos: los Republicanos trabajaban en brigadas "a pico y pala a dieciocho grados bajo cero de 7:00 a 7:00" y que algunos "señoritines nunca habíamos tomado pico y pala", así que "nos recomendaban orinarnos las manos para curtirlas porque sangraban". Muchos de los antiguos soldados republicanos lucharon contra los nazis en Francia y en otros puntos de Europa. Santiago Carrillo, en una clara defensa de su ideología, declara que debido precisamente a las "características del Partido Comunista", "las compañías se transforman de la noche a la mañana en unidades guerrilleras, en el sur de Francia; son una parte importante de los maquis". Y José Martínez Cobo comenta sobre la batalla de Narvik en Noruega: hubo tantas bajas españolas que en el cementerio de la batalla, "el 90\% de los apellidos son españoles". De los soldados españoles que fueron capturados y mandados a Mauthausen, este film ofrece el dato espeluznante de que de los nueve mil presos, solamente dos mil sobrevivieron. Pero también ofrece un testimonio que impacta al espectador por las fotos que acompañan las disposiciones: Luis García Manzano indica que los nazis liquidaban a los heridos, tirándolos por el precipicio de sesenta y cinco metros de la cantera; y Francisco Comellas declara que muchos presos estaban tan desesperados que se suicidaron: "abríamos la ventana y veíamos seis, siete, cuatro, ocho que se habían tirado al alambre eléctrico". Las fotos que confirman estos suicidios son impactantes.

De la misma manera, Exilio ofrece detalles adicionales sobre la emigración forzada a Rusia que no están en Los niños de Rusia. Isabel Argentina Álvarez declara: "Nos destinaron a distintos lugares, yo me quedé en Leningrado, otros fueron a Moscú, Kiev, Odessa". Antonio Martínez comenta: "Nos trataron bien, algunos dicen que fue por el oro español. Yo no tengo argumentos para rebatir esa teoría", pero "no hay oro del mundo que compre la amistad, 
generosidad, amabilidad [que mostraba] el pueblo común y corriente". Y de los españoles en Rusia, algunos pagaron con su vida durante la Segunda Guerra Mundial. El narrador informa que Rubén Ruiz, el hijo de Dolores Ibárruri murió en la batalla de Leningrado, y una secuencia de archivo muestra a la Pasionaria poniendo flores en su tumba.

Un hilo temático que corre a lo largo del documental es la ayuda que ofreció México. El Presidente Cárdenas mandó veinte mil fusiles al ejército republicano y, al terminar la guerra, garantizó los gastos de transporte marítimo a los exiliados.

Según Anselmo Carretero, "Todo español que llegara era bien recibido" y "nunca agradeceremos bastante lo que [México] hizo por los republicanos españoles". Y un detalle íntimo revela la mentalidad del exiliado en México. Francisca Gómez Díaz declara: "Mi padre nunca guardó la maleta detrás de la puerta como muchos exiliados porque sabía que nunca iba a regresar".

Un mapa indica los otros países latinoamericanos que recibieron a los exiliados y varios de ellos dan testimonio de la recepción de los republicanos. Concha Ruiz Funes comenta que en la mayoría de los países, el exilio fue fundamentalmente intelectual, y que quizá el único país que recibió el exilio no intelectual fue Santo Domingo. Observa que los intelectuales en Chile y la Argentina, como Neruda, se movieron para traer a los españoles. Francisco Ayala añade que la recepción en Buenos Aires fue "bastante buena" y que en la colonia republicana había "gente bien preparada".

La película termina con un montaje de fotos de los españoles que tuvieron que vivir en el exilio, muchos de ellos escritores y artistas famosos —Juan Ramón Jiménez, Cernuda, Alberti, Buñuel, Picasso-y así la película ayuda, según Alfredo Guevara, a "revindicar lo que significó la República española en todos los terrenos: ciencia, artes, literatura, política".

Exilio está concebido para dar una visión amplia de la emigración forzada después de la Guerra civil. Lo que en principio es algo positivo resulta ser un defecto, ya que trata de abarcar demasiado terreno en tan poco tiempo. Con unos 52 exiliados entrevistados, más algunos extranjeros (de Francia e Inglaterra) que también ofrecen testimonio, no logra mantener bien unos temas sostenidos. A veces incluye secuencias de archivo (la visita de Eva Perón, una entrevista radiofónica de la CBS norteamericana con Franco) que no se relacionan bien con el tema principal. Por otro lado, menciona casi de paso información importante, como los exiliados que vuelven a España para luchar en el Valle de Arán (ahora novelado por Almudena Grandes). El sueño derrotado y Exilio tienen otras lagunas también. Pilar Aguilar nota que uno de los sobrevivientes de los campos de concentración en Francia, Eulalio Ferrer, habla en su diario, Entre alambradas, de una condición mental común en los campos que los presos denominaban "arenitas": delusiones de estas personas que estaban forzadas a vivir en la playa cuyos síntomas consistían en que estaban convencidas de que sus familiares iban a buscarlos y llevarlos a Latinoamérica; a veces se ahogaban, entrando al mar vestidos con una maleta en la mano para tomar el barco que imaginaban que estaba amarrado allí. No hay mención de esto en ambos documentales.

Estas tres películas documentales figuran dentro del fenómeno de la recuperación de la memoria histórica, y son muy importantes ya que los sobrevivientes de esa guerra fratricida son cada vez menos y es una labor imprescindible grabar sus recuerdos. Este intento de recuperación tiene amplia resonancia en trabajos históricos, en el cine y en novelas. Pero la emigración forzada -el exilio- ha ocupado menos atención hasta hace poco. Estos documentales reflejan también una tendencia historiográfica de concebir la historia como "historia desde 
abajo". Sharpe (2001: 26) nota que Edward Thompson inventó este término (en inglés: history from below) en 1966. Este concepto contrasta con la noción tradicional de "la historia de arriba, en el sentido de que siempre se ha concentrado en las hazañas de grandes hombres, estadistas, generales, u ocasionalmente hombres de la iglesia", mientras que la historia de abajo tiene que ver con "las perspectivas de la gente común" (Burke, 2001:3). La historiadora Lisa Jardine comenta: "cuando nosotros los historiadores tratamos de recuperar el pasado, la primera persona, yo del testimonio oral, las voces de los que estaban allí, son particularmente seductoras. La fuerza de sus sentimientos se nos comunica de una manera que no podría hacerlo nunca un documento escrito. Nos conecta, nos obliga a prestar atención continuamente, nos impide olvidarlo nunca. En cuanto a los detalles fácticos, sin embargo [...] sospecho que sería buena idea cotejarlos por su exactitud histórica". (Web). Y Samuel Hynes (1999: 205), siguiendo las teorías de James Young, concluye que "los recuerdos escritos de hombres que realizaron actos que, en su conjunto, constituyen una guerra" deben ser considerados "gestos de conmemoración pública". Entonces los recuerdos orales en estos documentales también merecen serlos. Pero Hynes (1999: 207), al notar la importancia de estas narraciones personales, indica que lo importante no es "ninguna narración individual, sino narraciones colectivas" ya que el evento "toma su sustancia de la suma de muchas historias". Y aunque Hynes se refiere a la guerra, se puede decir lo mismo del exilio. Así, sumando y cotejando las diferentes voces e imágenes tanto dentro de cada documental como entre estos tres filmes, podemos conocer la realidad histórica de estos eventos. Pero Nichols (1991: 111) nos recuerda que un documental es "menos una historia y su mundo imaginario que un argumento sobre el mundo histórico", y Caroline Brothers (1997: 2), en su estudio sobre la fotografía de guerra, dice que hay que tener en mente que "a pesar de su aura de objetividad fortuita, las fotografías siempre se sacan dentro de términos específicos y deliberados" y que representan "la expresión visible de las aspiraciones y miedos de una sociedad". Y lo mismo se puede decir de películas documentales. Así que quizá lo más importante sea recordar lo que dicen los testigos mismos sobre sus narraciones. Julián Antonio Ramírez habla de la "necesidad de rescatar la verdadera historia de España de los últimos tiempos y la verdad de lo que ha sucedido y no solo en España sino en Francia también y en el mundo". En la misma película, Lluís Martí afirma: "Que nunca supieron los españoles que había en el campo de Argelés, no lo supieron nunca. Hoy todavía no lo saben". Y María Amparo Sánchez declara: "La Historia tiene una deuda muy grande con los republicanos españoles [...] porque no hay que olvidar que los republicanos españoles, esos mismos que metieron en campos de concentración, fueron de los primeros que salieron de esos campos, hambrientos, medio desnudos, pero fueron los primeros para seguir luchando contra el fascismo". El comentario de Carmen Parga, la primera entrevistada de Exilio, constituye la razón de ser de estas películas documentales y es un factor importante de la recuperación de la memoria histórica: "un pueblo que no conoce su historia está condenado a repetirla". Estos tres documentales informan y hacen pensar al espectador al dar voz a los protagonistas de este capítulo importante en la historia de España: la emigración forzada después de la Guerra civil española.

\section{BIBLIOGRAFÍA}

ABELLÁN, José Luis (1983). De la Guerra civil al exilio republicano (1936-1977). Madrid: Mezquita. 
AGUILAR, Pilar (1999). "Agents of Memory: Spanish Civil War veterans and disables soldiers". War and remembrance in the twentieth-century. Ed. Jay Winter and Emmanuel Sivan Cambridge: Cambridge UP, 84-103.

- (2003), "Approaches to and Diversity of International Migration". World Migration 2003: Managing Migration Challenges And Responses For People On The Move. Geneva, Switzerland: International Organization for Migration, 4-21.

BORDWELL, David and Kristin THOMPSON (1990). Film Art: An Introduction. New York: McGraw-Hill.

BROTHERS, Caroline (1997). War and Photography: a Cultural History. London: Routledge.

BURKE, Peter (2001). "Overture. The New History: Its Past and its Future." New Perspectives on Historical Writing. $2^{\text {nd }}$ ed. Ed. Peter Burke. University Park, PA: Penn State UP, 1-24.

CAMINO, Jaime (2001). Los niños de Rusia. Madrid: TVC, TVE, Tibidabo Films, S.A., Vía Digital, Wanda Visión.

CARVAJAL, Pedro (2002). Exilio. Madrid: TVE, Fundación Pablo Iglesias, Esdocu y MediaPark Idea.

GARCÍA FERNÁNDEZ, Jesús (1965). La emigración exterior de España. Barcelona: Ariel.

HYNES, Samuel (1999). "Personal narratives and conmemoration". In War and Remembrance in the Twentieth Century. Ed. Jay Winter and Emmanual Sivan. Cambridge, England: Cambridge UP.

ILIE, Paul (1980). Literature and Inner Exile: Authoritarian Spain 1939-75. Baltimore: John Hopkins UP.

JARDINE, Lisa (2010). "Do our memories get better or worse with age?" BBC News. Web 7-IX- 2010.

MARSHALL, Barbara (2006). Introduction at The Politics Of Migration: A Survey. London: Routledge, 3-11.

NORA, Pierre (1984). Les lieux de mémoire. I. La République. Paris: Gallimard.

NICHOLS, Bill (1991). Representing Reality. Issues and Concepts in Documentary. Bloomington, IND: Indiana U P.

SERRA, Daniel y Jaime (2004). El sueño derrotado. Barcelona: S.A.V.

SHARPE, Jim (2001). "History from Below". New Perspectives on Historical Writing. $2^{\text {nd }}$ ed. Ed. Peter Burke. University Park, PA: Penn State UP, 25-42.

THOMAS, Hugh (1977). The Spanish Civil War. New York: Harper \& Row. 